\title{
Viral dynamics in the surface water of the western South China Sea in summer 2007
}

\author{
Xihan Chen ${ }^{1,6}$, Hongbin Liu ${ }^{1,2, *}$, Markus Weinbauer ${ }^{3,4}$, Bingzhang Chen ${ }^{1}$, \\ Nianzhi Jiao ${ }^{5}$ \\ ${ }^{1}$ Division of Environment, and ${ }^{2}$ Division of Life Science, Hong Kong University of Science and Technology, \\ Clear Water Bay, Kowloon, Hong Kong SAR \\ ${ }^{3}$ Microbial Ecology \& Biogeochemistry Group, Université Pierre et Marie Curie-Paris 6, \\ Laboratoire d'Océanographie de Villefranche, 06230 Villefranche-sur-Mer, France \\ ${ }^{4}$ CNRS-INSU, Laboratoire d'Océanographie de Villefranche, 06230 Villefranche-sur-Mer, France \\ ${ }^{5}$ State Key Laboratory of Marine Environmental Science, Xiamen University, Xiamen 361005, PR China \\ ${ }^{6}$ Present address: Center for Geomicrobiology, Aarhus University, Ny Munkegade 114, 8000 Aarhus C, Denmark
}

\begin{abstract}
We investigated viral dynamics in the surface seawater at 13 stations in the western South China Sea (SCS) during the summer of 2007; 2 cold eddies formed during the sampling period. We found modest viral production and viral decay rates. Colloidal and heat-labile substances were important causes of viral removal (range 9.47 to $55.64 \%$ of viral production). During the sampling period, 26.44 to $96.08 \%$ (average $77.82 \%$ ) of bacterial production was lysed by viruses, and a highly significant positive relationship was found between the rate of virus-induced bacterial mortality $(\mathrm{m})$ and bacterial growth rate $(\mu)$. According to the hydrological conditions and station location, the 13 stations investigated in the SCS were further subdivided into 4 regions: Cold Eddy I (CE I), Cold Eddy II (CE II), oligotrophic oceanic water (OO water) and Mekong River plume (MR plume). Overall, viral activities appeared more dynamic in mesotrophic cold eddies and in the river plume than in oligotrophic SCS waters. However, a significantly lower bacterial growth rate, virus-induced bacterial mortality rate and $m / \mu$, together with a high burst size in the MR plume compared to the CE I, CE II and the $\mathrm{OO}$ water, indicates that bacterial and viral activities have distinct responses to the upwelling of cold subsurface waters and the freshwater plume. Our results demonstrate that viral lysis is an important cause of loss of bacterial production in the SCS in summer, which may enhance $\mathrm{CO}_{2}$ emission to the atmosphere by respiratory processes.
\end{abstract}

KEY WORDS: South China Sea $\cdot$ Virus · Viral production · Viral decay rate $\cdot$ Virus-induced bacterial mortality rate $\cdot$ Bacterial growth rate

\section{INTRODUCTION}

In the last 2 decades, the ecological role of viruses in marine microbial food webs has been well documented (Fuhrman 1999, Weinbauer 2004). Viral lysis recycles bacterial production back into the dissolved organic carbon pool through the viral shunt and enhances $\mathrm{CO}_{2}$ emissions by bacterial respiration (Wilhelm \& Suttle 1999). It has been reported that viruses could cause a mortality rate of picoplankton comparable to grazing effects in freshwater and marine systems (Fuhrman \& Nobel 1995, Wommack \& Colwell 2000). In order to better understand the role of viruses in oceanic microbial processes, it is necessary to have a clear understanding of viral dynamics, exemplified in viral abundance, production, decay rate, turnover, virus-induced bacterial mortality and burst size. 
Previous studies have shown that the distribution of viral abundance is related to hydrological features such as temperature, salinity or water depth - and the trophic state of the water column has been proposed as a possible driving force controlling the spatial distribution of viruses (Cochlan et al. 1993, Weinbauer et al. 1993, Hara et al. 1996). Viral abundance is greater in productive and nutrient-rich environments, and it is significantly correlated with chlorophyll a (chl a) and primary production (Wommack \& Colwell 2000). However, Corinaldesi et al. (2003) has reported that changing trophic and hydrodynamic conditions do not directly influence viral distribution, but do influence bacterial activity and host cell abundance.

An accurate evaluation of viral production and viral decay rate is critical for determining potential changes in viral numbers in space and time (Noble \& Fuhrman 2000). Viral production can be high in non-steady-state systems, such as tidally driven mixing (Wilhelm et al. 2002), and various studies have shown that the highest viral production occurs in eutrophic waters and the lowest in oligotrophic coastal waters (Hewson et al. 2001, Bongiorni et al. 2005). The higher viral production in eutrophic waters is caused by higher bacterial production and host cell metabolic activities. Many factors, such as ultraviolet radiation, absorption onto particles, temperature, colloidal and heat-labile substances (extracellular enzymes), grazing, lysogenic infection and other, unknown, factors are involved in removing viruses from the water (i.e. viral decay) (Payment et al. 1988, González \& Suttle 1993, Noble \& Fuhrman 1997, Wilhelm et al. 1998, Binder 1999, Bongiorni et al. 2005, De Paepe \& Taddei 2006). Viral decay rates in the surface seawater have been reported to vary over 3 orders of magnitude across different methodologies (reviewed by Parada et al. 2007). Although temperature has proved to be an important factor determining viral decay rates (Parada et al. 2007), another study also shows that viral decay rates decrease along the trophic gradient (eutrophic to oligotrophic) (Bongiorni et al. 2005). The mechanisms for removal of viruses in eutrophic and oligotrophic waters are different: colloidal and heat-labile substances, absorption onto particles and grazing have accounted for more than $90 \%$ of viral production in eutrophic waters, while these factors have accounted for less than $10 \%$ of viral production in oligotrophic waters (Bongiorni et al. 2005).

Estimation of virus-induced bacterial mortality is crucial for quantifying the effects of viral lysis on the cycling of dissolved organic matter. Some studies indicate that virus-induced bacterial mortality strongly depends on trophic conditions (Weinbauer et al. 1993, Noble \& Fuhrman 2000, Weinbauer et al. 2003). For example, Noble \& Fuhrman (2000) have reported a potential increased impact of viruses on bacteria in the absence of protists in nearshore and meso-oligotrophic waters and a possible decreased impact of viruses in offshore waters. However, a separate study by the same authors indicated that virus-induced bacterial mortality was not directly related to trophic status (Noble \& Fuhrman 1999). Thus, it seems that the factors determining virus-induced bacterial mortality are still not well understood.

Viral dynamics have been less well studied in oligotrophic open oceans than in coastal and estuarine environments. The South China Sea (SCS) is the second largest marginal sea in the world. It is characterized by an oligotrophic central basin and is influenced by large rivers, such as the Mekong and Pearl Rivers. Cyclonic and anticyclonic eddies, which play a very important role in the biogeochemical processes in the ocean (Falkowski et al. 1991, McGillicuddy et al. 1998, Bidigare et al. 2003), often occur in various parts of the SCS (e.g. Wang et al. 2008 and references therein).

To date, viral dynamics and the effects of viruses on bacteria have not been well studied in the SCS. Here, we report a thorough study of viral production, viral decay, and virus-induced bacterial mortality for the first time in the western SCS. In particular, we focus on the 2 eddies that developed during the cruise.

\section{MATERIALS AND METHODS}

Sampling stations. A total of 13 stations were investigated during a cruise in the SCS from 10 August to 14 September 2007 (Fig. 1). A major feature of the cruise was the formation of 2 cold eddies during the sampling period. The center of Cold Eddy I (CE I) was located at $14.25^{\circ} \mathrm{N}, 111.75^{\circ} \mathrm{E}$ (Stn TS-1), and CE I covered Stns YS06 and YS12; the center of Cold Eddy II (CE II) was located at $12.50^{\circ} \mathrm{N}, 111.00^{\circ} \mathrm{E}$, and CE II covered Stns Y03, Y00 and Y20. In addition, a bloom of Trichodesmium spp. was observed at Stn YS12 during the sampling period. At each station, $20 \mathrm{l}$ of surface seawater were collected in a bucket and then immediately transferred to a $20 \mathrm{l}$ acid-rinsed polycarbonate carboy. Water samples were first taken for measurements of chlorophyll a ( $\mathrm{chl} \mathrm{a}$ ) and the abundance of heterotrophic bacteria and viruses; the remaining water was processed within $1 \mathrm{~h}$ for setting up experiments on virus-induced bacterial mortality rate, viral decay rate and viral production. Temperature and salinity measurements were obtained using a Sea Bird Electronics SBE 911 conductivity-temperature-depth (CTD) sensor.

Chlorophyll a. Seawater $(150 \mathrm{ml})$ was filtered through GF/F glass-fiber filters (Whatman) on board ship and then transferred to liquid nitrogen until 


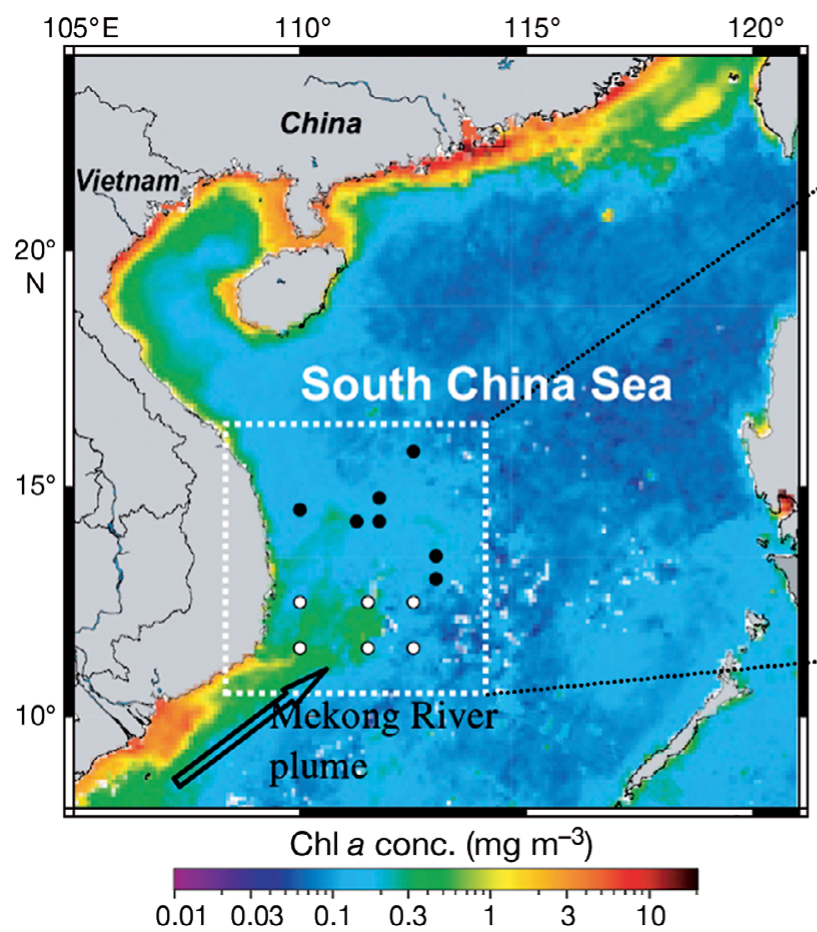

analysis in the laboratory. Chl a was extracted using $90 \%$ acetone at $4^{\circ} \mathrm{C}$ for $24 \mathrm{~h}$ and then determined by fluorescence analysis with a Shimadzu RF-5301PC spectrofluorometer (Parsons et al. 1984).

Bacterial and viral abundance. Seawater samples (2 ml) were taken for analysis of prokaryotes and viral abundance. Samples were fixed with EM-grade glutaraldehyde (1\% final conc.) which had been filtered through an $\mathrm{Al}_{2} \mathrm{O}_{3}$ Anodisc membrane of pore size $0.02 \mu \mathrm{m}$ (Whatman); fixation was carried out for $15 \mathrm{~min}$ at $4^{\circ} \mathrm{C}$ in the dark, and the samples were then stored at $-80^{\circ} \mathrm{C}$ until analysis (Vaulot et al. 1989). The procedures below are according to Olson et al. (1990). The abundance of total heterotrophic bacteria and viruses was determined using an Epics Altra II flow cytometer equipped with an air-cooled argon-ion laser (15 mw, 488 nm; Beckman Coulter). The heterotrophic bacterial samples were stained with $0.02 \%$ SYBR Green I (Molecular Probes) for $15 \mathrm{~min}$ in the dark and then analyzed for $100 \mathrm{~s}$ at a rate of 0.1 to $1 \mathrm{ml} \mathrm{h}^{-1}$. Viral samples were initially diluted with TE buffer (10 mM Tris, 1 mM EDTA, pH 8.0) which had been filtered through an $\mathrm{Al}_{2} \mathrm{O}_{3}$ Anodisc membrane of pore size $0.02 \mu \mathrm{m}$; the samples were then incubated with $0.02 \%$ SYBR Green I at $80^{\circ} \mathrm{C}$ for $10 \mathrm{~min}$ (Brussaard 2004). After cooling for $5 \mathrm{~min}$, viral samples were immediately analyzed for $100 \mathrm{~s}$ at a rate of 0.1 to $1 \mathrm{ml} \mathrm{h}^{-1}$. The discriminator was set on green fluorescence for both bacteria and viruses. All the samples were analyzed twice at an event rate of about 200 events $\mathrm{s}^{-1}$, and more than

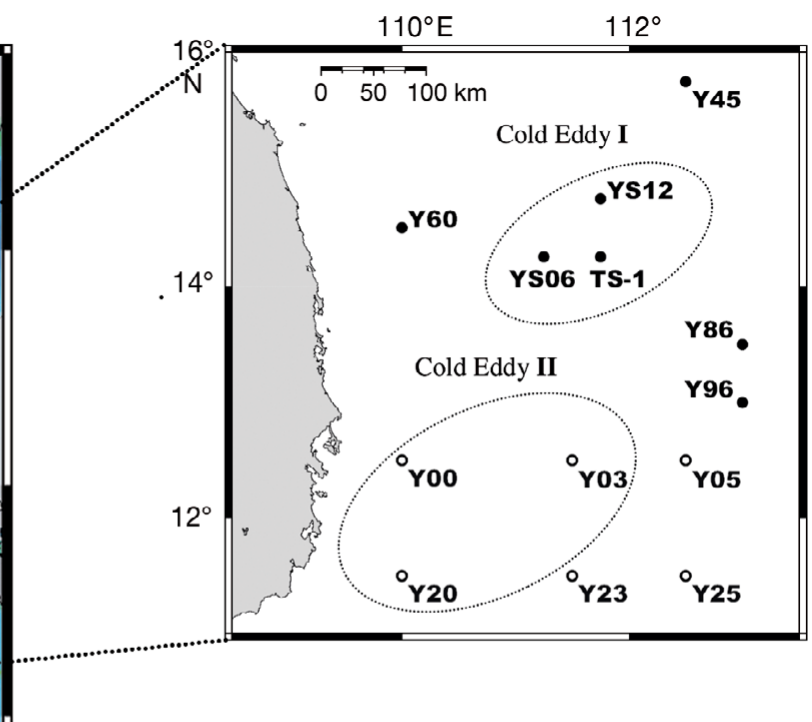

Fig. 1. Sampling stations in the South China Sea in the summer of 2007. The distribution of chlorophyll $a$ in the region, retrieved from SeaWiFS, is shown (left panel). = stations in the northern area; $\mathrm{O}=$ stations in the southern area

10000 events were accumulated. Data were analyzed using FCS Express V3 software (De Novo Software).

Experimental set-up. We designed the following experiments to estimate virus-induced bacterial mortality rate, viral decay rate and viral production. 101 of seawater were initially filtered through a Maxi Capsule (Pall) of pore size $0.22 \mu \mathrm{m}$ and then processed with a spiralwound ultrafiltration cartridge with a molecular weight cut-off of $100 \mathrm{kDa}$ (Prep/Scale Spiral Wound TFF-6 Module PTHK, Millipore) to produce the virus-free seawater.

Viral lysis: The virus-induced bacterial mortality rate was estimated by the 'virus dilution approach' of Jacquet et al. (2005), which is a modification of the dilution method of Landry \& Hassett (1982). Seawater was filtered twice through polycarbonate filters of pore size $2 \mu \mathrm{m}$ (GE Water \& Process Technologies) to exclude all grazers. The $2 \mu \mathrm{m}$ filtrates were diluted with the virus-free seawater at a series of dilution gradients, i.e. $20,40,70$ and $100 \%$ in $150 \mathrm{ml}$ polycarbonate bottles. A control containing only virus-free seawater was also set up in parallel. Duplicates were prepared and incubated in a bath cooled by running seawater and exposed to natural sunlight for $24 \mathrm{~h}$. Samples for the enumeration of bacteria were taken at times 0 and $24 \mathrm{~h}$. The apparent growth rate in $24 \mathrm{~h}(\mathrm{k}$, $\mathrm{d}^{-1}$ ) was calculated by:

$$
\mathrm{k}=\left[\ln \left(N_{24 \mathrm{~h}} / N_{0 \mathrm{~h}}\right)\right] / 1 \mathrm{~d}
$$

where $N_{0 \mathrm{~h}}$ and $N_{24 \mathrm{~h}}$ represent the bacterial abundance at 0 and $24 \mathrm{~h}$, respectively. The intrinsic bacterial 
growth rate $\left(\mu, \mathrm{d}^{-1}\right)$ and the virus-induced bacterial mortality rate $\left(m, \mathrm{~d}^{-1}\right)$ were calculated as the $y$-intercept and slope of linear regression fitted to the apparent growth rates (all bottles in duplicate dilution series) plotted against dilution factors (see Fig. 4). A carbon budget was also calculated using $\mu$ combined with a value of bacterial cellular carbon content from the literature $\left(1.1 \times 10^{-8} \mu \mathrm{g} \mathrm{C} \mathrm{cell}^{-1}\right)$ (Liu et al. 2007).

Bacterial production (BP, $\mu \mathrm{g} \mathrm{Cl}^{-1} \mathrm{~d}^{-1}$ ) was calculated by the formula:

$$
\mathrm{BP}=\mu \times \mathrm{BA} \times\left(1.1 \times 10^{-8}\right) \times 1000\left(\mathrm{ml} \mathrm{l}^{-1}\right)
$$

where BA is bacterial abundance (cells $\mathrm{ml}^{-1}$ ).

Virus-induced loss of bacterial production $\left(\mathrm{BP}_{\text {Loss }} \mathrm{\mu g}\right.$ $\mathrm{C}^{-1} \mathrm{~d}^{-1}$ ) was calculated by the formula:

$$
\mathrm{BP}_{\text {Loss }}=m \times \mathrm{BA} \times\left(1.1 \times 10^{-8}\right) \times 1000\left(\mathrm{ml} \mathrm{l}^{-1}\right)
$$

Viral decay rate: The viral decay rate was estimated following Noble \& Fuhrman (1997). Seawater (600 ml) was filtered through polycarbonate filters (pore size $0.22 \mu \mathrm{m}$, GE Water \& Process Technologies), filled into triplicate $150 \mathrm{ml}$ polycarbonate bottles, and then incubated in a temperature-controlled bath in the dark for $12 \mathrm{~h}$. Subsamples were collected to enumerate viruses at regular intervals ( 2.5 to $3 \mathrm{~h}$ ). The viral decay rate in each bottle was calculated as the slope of the linear regression fitted to the natural logarithm of viral abundance plotted against time (Fig. 2a), and the average rate from triplicate bottles was used as the in situ viral decay rate. Because grazers, bacteria and large particles were excluded, and the bottles were incubated in the dark, the major factor causing viral decay in this study was colloidal and heat-labile substances.

Viral production: Viral production was estimated using a 'modified virus dilution approach' (Bongiorni et al. 2005) originating from the 'virus reduction approach' developed by Wilhelm et al. (2002). Triplicates of $20 \mathrm{ml}$ of seawater were transferred to $150 \mathrm{ml}$ polycarbonate bottles, and the bottles were then filled with virus-free seawater and incubated in the dark for $12 \mathrm{~h}$; the bottles were cooled by running seawater. Subsamples were collected to enumerate viruses at regular intervals $(2.5$ to $3 \mathrm{~h}$ ). Apparent viral production was calculated for every bottle ( $\left.\mathrm{AVP}_{\text {bottle }}\right)$. Generally, there were 5 patterns relating to the curve of viral abundance versus incubation time (Fig. 2b,c). $\mathrm{AVP}_{\text {bottle }}$ was calculated by different methods based on the peaks of viral abundance, $V$, during incubation. For curves with only 1 peak (Fig. 2b), $\mathrm{AVP}_{\text {bottle }}$ was calculated as follows: patterns $i$ and $i i i$, the slope of linear regression fitted to viral abundance plotted against time; and pattern ii, the slope of the curve between $V_{\max }$ and $V_{\min }$. For curves with 2 peaks (Fig. 2c): patterns iv and $V, \mathrm{AVP}_{\text {bottle }}$ was calculated by the formula:
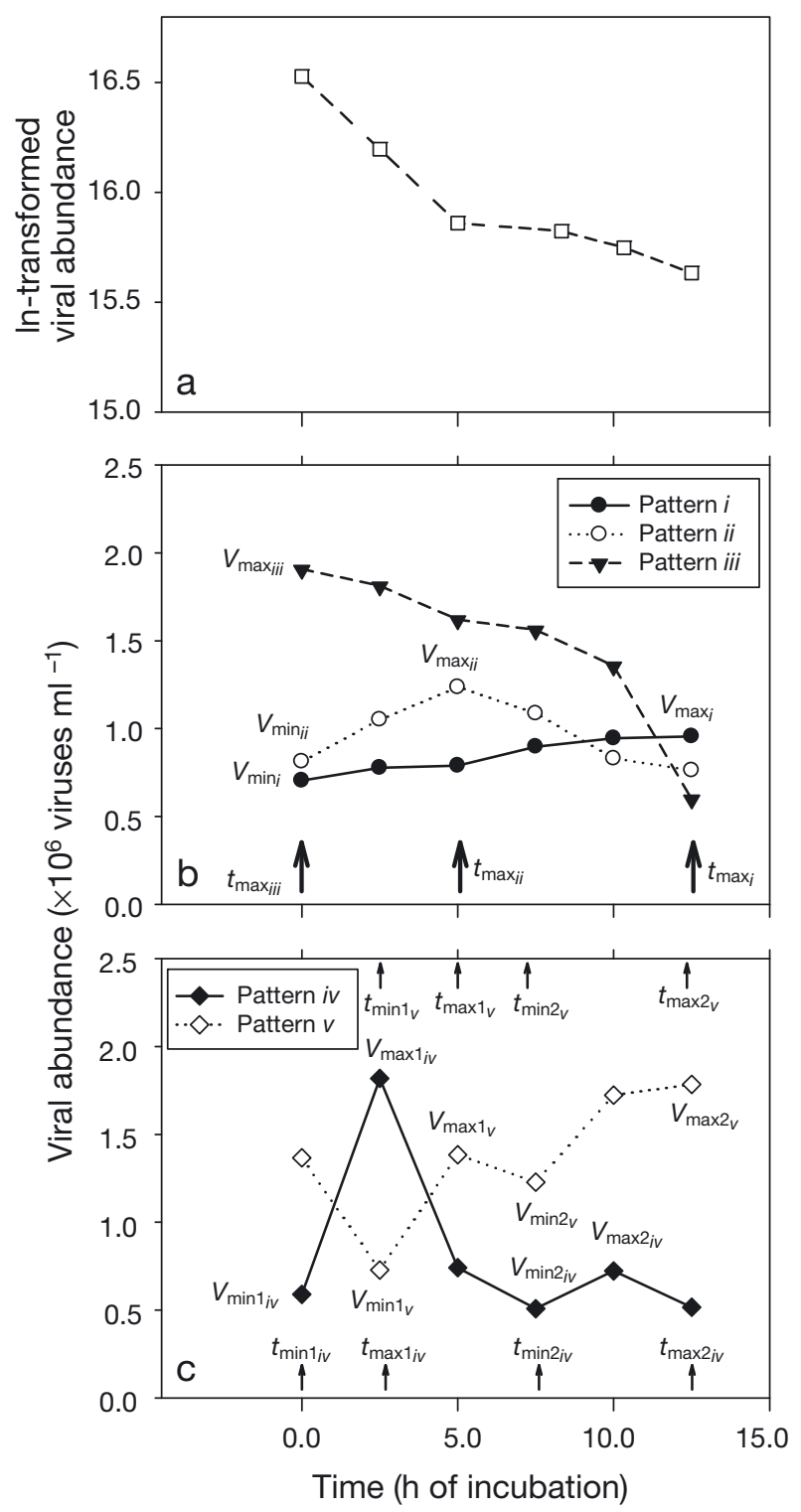

Fig. 2. (a) Example of the development of viral abundance, over time, in the viral decay incubation bottle (Stn Y20). (b,c) Five patterns of development of viral abundance, over time, in the viral production dilution incubation bottles, with pattern $i$ (•) observed at Stn YS12, pattern ii (O) at Stn Y25, pattern iii $(\boldsymbol{\nabla})$ at Stn Y96, pattern iv $(\diamond)$ at Stn Y60 and pattern $v(\diamond)$ at Stn Y03. Viral abundance ( $V_{\min }$ and $V_{\max }$ for patterns $i$, ii and iii; $V_{\min 1}, V_{\max 1}, V_{\min 2}$ and $V_{\max 2}$ for patterns $i v$ and $v$ ) and corresponding time points $\left(t_{\min }\right.$ and $t_{\max }$ for patterns $i$, ii and iii; $t_{\min 1}, t_{\max 1}, t_{\min 2}$ and $t_{\max 2}$ for patterns $i v$ and $v$ ), used for calculating viral production in bottles, are shown

$\mathrm{AVP}_{\text {bottle }}=\left[\left(V_{\max 1}-V_{\min 1}\right)+\left(V_{\max 2}-V_{\min 2}\right)\right] /\left(t_{\max 2}-t_{\min 1}\right)$

where $t=$ time.

$\mathrm{AVP}_{\text {bottle }}$ was corrected by multiplying by the ratio of bacterial abundance in the station to bacterial abundance at time $0 \mathrm{~h}$ in a specific bottle $\left(\mathrm{BA}_{\text {station }}\right.$ / 
$\left.\mathrm{BA}_{\text {bottleoh }}\right)$, and the average values of triplicate bottles were treated as apparent viral production of the station $\left(\mathrm{AVP}_{\text {station }}\right)$. Finally, in situ viral production of the station $\left(\mathrm{VP}_{\text {station, }}\right.$ viruses $\left.\mathrm{ml}^{-1} \mathrm{~h}^{-1}\right)$ was acquired as the sum of $\mathrm{AVP}_{\text {station }}$ and the loss of viruses due to viral decay during the incubation:

$$
\begin{gathered}
\mathrm{VP}_{\text {station }}=\text { Average }\left(\mathrm{AVP}_{\text {bottle }} \times \mathrm{BA}_{\text {station }} / \mathrm{BA}_{\text {bottleoh }}\right)+ \\
\operatorname{VA}_{\text {station }} \times\left(1-\mathrm{e}^{-\mathrm{VDR}}\right)
\end{gathered}
$$

where $\mathrm{VA}_{\text {station }}$ is in situ viral abundance of the station and VDR is viral decay rate.

Viral turnover and burst size: Viral turnover time was calculated by dividing the in situ viral abundance with viral production. Burst size (viruses cell-1 ${ }^{-1}$ was calculated using the following formula:

$$
\text { Burst size }=\left[\mathrm{VP}_{\text {station }} \times 24(\mathrm{~h})\right] /[\mathrm{BA} \times \mathrm{m}]
$$

Statistics. A Pearson correlation matrix (SPSS version 13.0) was calculated to describe the correlations between temperature, salinity, chl $a_{1} \mathrm{SiO}_{3}{ }^{2-}$, bacterial and viral abundance, ratio of viral to bacterial abundance (VBR), bacterial growth rate, virus-induced bacterial mortality rate, viral decay rate, viral production, bacterial production, virus-induced loss of bacterial production, viral turnover time, and burst size. A single linear regression was conducted using SigmaPlot 10.0. Analysis of variance (ANOVA) and LSD Posthoc tests were used to assess differences in parameters between environments using the statistical software SPSS 13.0. A probability (p) of $<0.05$ was considered significant. Data were log transformed before analysis when necessary to meet the requirements of normal distribution.

\section{RESULTS}

\section{Hydrographic features}

Based on temperature and salinity, the 13 stations investigated were divided into 4 types of water: CE I (Stns TS-1, YS06 and YS12), CE II (Stns Y03, Y00 and Y20), oligotrophic oceanic water (OO water; Stns Y96, Y86, Y60 and Y45) and Mekong River plume (MR plume; Stns Y05, Y23 and Y25) (Table 1, Fig. 1). CE I was evident from the temperature and salinity distribution, while CE II was only partly covered by our sampling efforts - an intact CE II was not visible (Fig. 3a,b). The MR plume could be traced from reduced salinity and increased temperature compared to the surrounding waters (Table 1, Fig. 3a,b). In addition, CE II should have some residual Mekong River freshwater plume, which is illustrated by the distribution of chl $a$ in the SCS in the summer of 2007, retrieved from SeaWiFS (Fig. 1). Inorganic nitrogen and phosphorus concentrations in the surface mixed layer were all below the detection limit of colorimetric methods (M. Dai pers. comm.), but the concentration of silicate was measurable (Table 1).

Table 1. Physical characteristics, nutrients and chlorophyll a concentrations of the surface seawater in the western South China Sea; absolute values and means \pm SD are shown. Lat. = latitude; Long. = longitude; Temp. $=$ temperature; Sal. $=$ salinity; chl $a=$

\begin{tabular}{|c|c|c|c|c|c|c|c|c|}
\hline Area & Water & Stn & Lat. $\left({ }^{\circ} \mathrm{N}\right)$ & Long. $\left({ }^{\circ} \mathrm{E}\right)$ & Temp. $\left({ }^{\circ} \mathrm{C}\right)$ & Sal. (PSU) & $\mathrm{Chl} \mathrm{a}\left(\mu \mathrm{g} \mathrm{l} \mathrm{l}^{-1}\right)$ & $\mathrm{SiO}_{3}{ }^{2-}(\mu \mathrm{M})$ \\
\hline \multirow[t]{7}{*}{ Northern } & CE I & TS-1 & 14.25 & 111.75 & 27.6 & 34.1 & 0.168 & 2.20 \\
\hline & & YS06 & 14.25 & 111.25 & 28.9 & 33.8 & 0.109 & 2.23 \\
\hline & & YS12 & 14.75 & 111.75 & 28.9 & 34.1 & 0.145 & 2.44 \\
\hline & OO water & Y96 & 13.00 & 113.00 & 28.1 & 33.5 & 0.080 & 2.30 \\
\hline & & Y86 & 13.50 & 113.00 & 28.2 & 33.6 & 0.081 & 2.26 \\
\hline & & Y60 & 14.50 & 110.00 & 29.2 & 33.7 & 0.063 & 2.45 \\
\hline & & Y45 & 15.75 & 112.50 & 29.4 & 33.4 & 0.068 & 2.4 \\
\hline \multirow[t]{6}{*}{ Southern } & CE II & Y03 & 12.50 & 111.50 & 28.4 & 33.3 & 0.171 & 1.35 \\
\hline & & Y00 & 12.50 & 110.00 & 29.2 & 33.8 & 0.094 & 1.73 \\
\hline & & Y20 & 11.50 & 110.00 & 28.4 & 33.9 & 0.124 & 2.86 \\
\hline & MR plume & Y23 & 11.50 & 111.50 & 29.3 & 32.5 & 0.144 & 1.46 \\
\hline & & Y05 & 12.50 & 112.50 & 29.3 & 32.8 & 0.104 & 2.60 \\
\hline & & Y25 & 11.50 & 112.50 & 29.5 & 32.3 & 0.139 & 1.00 \\
\hline \multirow[t]{3}{*}{ South China Sea } & & & & & $28.80 \pm 0.60$ & $33.45 \pm 0.58$ & $0.115 \pm 0.037$ & $2.10 \pm 0.55$ \\
\hline & Northern & & & & $28.61 \pm 0.66$ & $33.74 \pm 0.28$ & $0.102 \pm 0.041$ & $2.33 \pm 0.10$ \\
\hline & Southern & & & & $29.02 \pm 0.49$ & $33.10 \pm 0.67$ & $0.129 \pm 0.028$ & $1.83 \pm 0.74$ \\
\hline \multirow[t]{2}{*}{ Northern } & CE I & & & & $28.47 \pm 0.75$ & $34.00 \pm 0.17$ & $0.141 \pm 0.030$ & $2.29 \pm 0.13$ \\
\hline & OO water & & & & $28.73 \pm 0.67$ & $33.55 \pm 0.13$ & $0.073 \pm 0.009$ & $2.35 \pm 0.09$ \\
\hline \multirow[t]{2}{*}{ Southern } & CE II & & & & $28.67 \pm 0.46$ & $33.67 \pm 0.32$ & $0.130 \pm 0.039$ & $1.98 \pm 0.79$ \\
\hline & MR plume & & & & $29.37 \pm 0.12$ & $32.53 \pm 0.25$ & $0.129 \pm 0.022$ & $1.69 \pm 0.82$ \\
\hline
\end{tabular}
chlorophyll $a$. Abbreviations for the 4 types of water studied: CE I = Cold Eddy $\mathrm{I}_{\text {; }} \mathrm{OO}$ water = oligotrophic oceanic water; CE II = Cold Eddy II; MR plume = Mekong River plume 

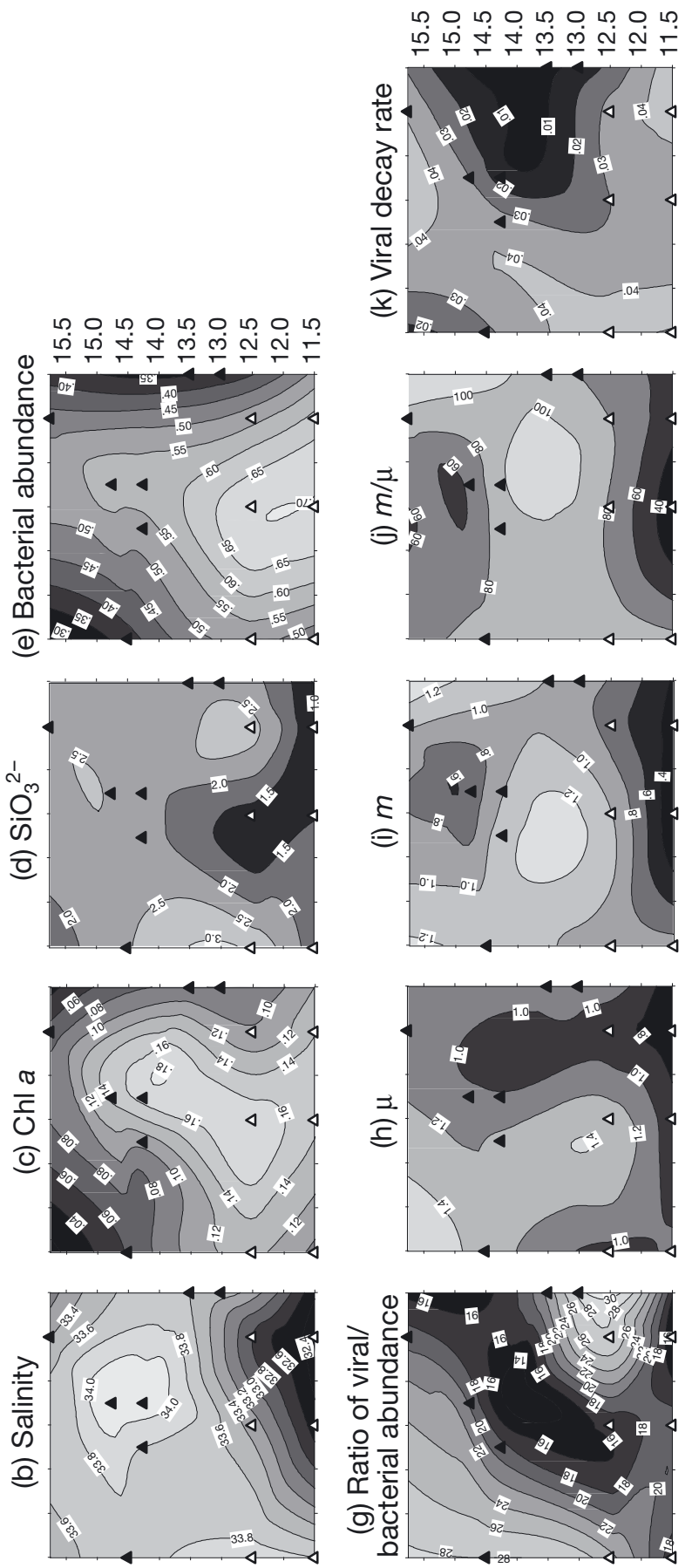

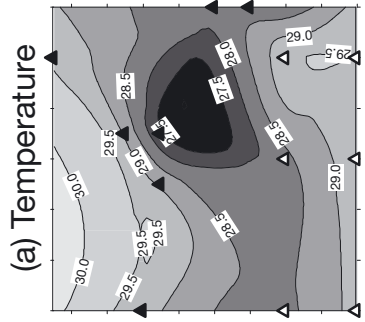

L

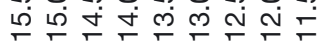

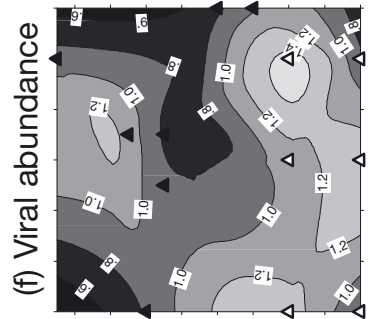

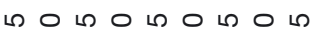

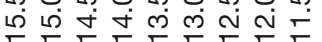

L
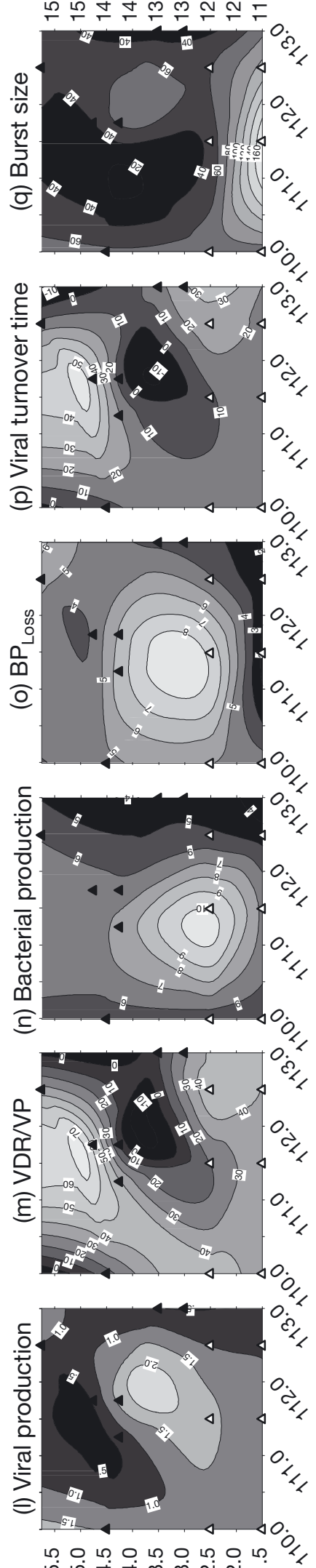

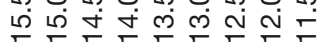

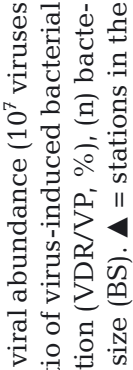

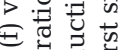

I: 03

द्व

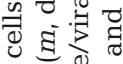

을

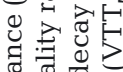

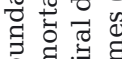

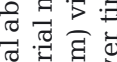

प्ष

0 군

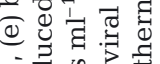

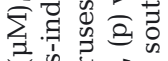

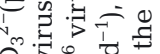

is 0 :

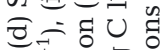

1-

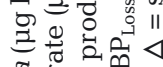

ช.

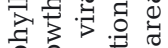

웡영

웡. 명

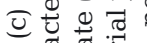

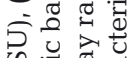

记.

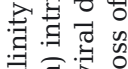

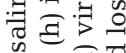

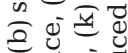

पित के

०

둥. 줌 㐘

要

हैं

조요 히

岩零

동

글 융

ज可:

ल =

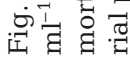




\section{Chlorophyll a}

Surface chl a varied from 0.063 to $0.171 \mu \mathrm{g}^{-1}$ among the stations investigated, with an average of $0.115 \pm$ $0.037 \mathrm{ug} \mathrm{l}^{-1}$ (n=13; Table 1). Generally, chl a was significantly lower in the OO water than in the other 3 types of water-CE I and II and the MR plume (ANOVA, $\mathrm{p}<0.05, \mathrm{n}=13$ ) while chl a among the latter 3 waters was comparable and displayed no significant difference (ANOVA, p > $0.05, \mathrm{n}=13$ ).

\section{Bacterial abundance}

Heterotrophic bacterial abundance was low in the surface water during our cruise, ranging from 0.35 to $0.70 \times$ $10^{6}$ cells $\mathrm{ml}^{-1}$ (average $0.52 \pm 0.11 \times$ $10^{6}$ cells $\mathrm{ml}^{-1}, \mathrm{n}=13$; Table 2 ). The highest concentration was found at Stn Y23 in the MR plume, and the lowest at Stn Y86 in the OO water, respectively (Table 2, Fig. 3e). Bacterial abundance in the $\mathrm{OO}$ water was significantly lower (ANOVA, $\mathrm{p}<0.05, \mathrm{n}=13$ ) than in the other 3 waters (Table 2; Fig. 3e), whereas no significant differences existed between CE I, CE II and the MR plume. Bacterial abundance was positively related to chl a (Pearson's, r = 0.850, $\mathrm{p}<0.01, \mathrm{n}=13$; Table 3).

\section{Viral abundance}

Viral abundance varied from $0.76 \times 10^{7}$ to $1.44 \times 10^{7}$ viruses ml $\mathrm{m}^{-1}$ (average $1.00 \pm 0.23 \times 10^{7}$ viruses $\mathrm{ml}^{-1}, \mathrm{n}=$ 13) (Table 2). The highest abundance was found at Stn Y05 $\left(1.44 \pm 0.09 \times 10^{7}\right.$ viruses $\left.\mathrm{ml}^{-1}\right)$ in the MR plume, whereas the lowest was found at Stn Y86 $(0.76$ $\pm 0.11 \times 10^{7}$ viruses $\mathrm{ml}^{-1}$ ) in the OO water (Table 2, Fig. 3f). Viral abundances among the 4 types of water were not significantly different from each other (ANOVA, $\mathrm{p}>0.05, \mathrm{n}=13$; Table 2). Viral abundance was neither correlated with chl a (Pearson's, $r=0.309$, $\mathrm{p}>0.05, \mathrm{n}=13$; Table 3 ) nor with bacterial abundance (Pearson's, $\mathrm{r}=0.463, \mathrm{p}>0.05, \mathrm{n}=13$; Table 3 ).

VBR ranged from 14 to 27 (average $20.38 \pm 5.16, \mathrm{n}=$ 13; Table 2). The higher VBR was found in the OO water (average $23.50 \pm 3.70$ ), and the lower VBR (average $17.33 \pm 3.06$ ) was found in CE I (Table 3). There were no significant differences of VBR among different waters (ANOVA, $\mathrm{p}>0.05, \mathrm{n}=13$; Table 2,
Fig. 3g). A positive relationship was observed between VBR and $\mathrm{SiO}_{3}{ }^{2-}$ (Pearson's, $\mathrm{r}=0.693, \mathrm{p}<0.01, \mathrm{n}=13$; Table 3).

\section{Bacterial growth rate, virus-induced bacterial mortality rate, bacterial production and virus- induced loss of bacterial production}

The results of viral lysis based on the 'virus dilution approach' are shown in Fig. 4. The bacterial growth rate averaged $1.05 \pm 0.19 \mathrm{~d}^{-1}$, with the highest at Stn Y60 (1.32 $\mathrm{d}^{-1}$, in the OO water) and lowest at Stn Y25 (0.66 $\mathrm{d}^{-1}$, in the MR plume) (Table 4, Fig. 3h). Bacterial growth rates were comparable in CE I and II and the OO water (average 1.10 $\pm 0.13,1.09 \pm 0.19$, $1.17 \pm 0.10 \mathrm{~d}^{-1}$, respectively; Table 4, Fig. 3h). Bacterial growth rates in the MR plume (average $0.81 \pm 0.13 \mathrm{~d}^{-1}$ ) were significantly lower than in other waters (Table 4 , Fig. 3h). The bacterial growth rate was positively correlated with salinity (Pearson's, $\mathrm{r}=0.635, \mathrm{p}<0.05, \mathrm{n}=$ 13; Table 3).

The virus-induced bacterial mortality rate $(m)$ varied from $0.23 \mathrm{~d}^{-1}$ (Stn Y23, in the MR plume) to $1.15 \mathrm{~d}^{-1}$ (Stn Y60, in the OO water), and the average mortality rate among the 13 stations investigated was $0.84 \pm$ $0.28 \mathrm{~d}^{-1}$ (Table 4). Mortality rates were extremely low at Stns Y23 and Y25 (0.23 and $0.32 \mathrm{~d}^{-1}$, respectively), both of which are located in the MR plume (Table 4, Fig. 3i). Mortality rates were comparable in CE I, CE II 


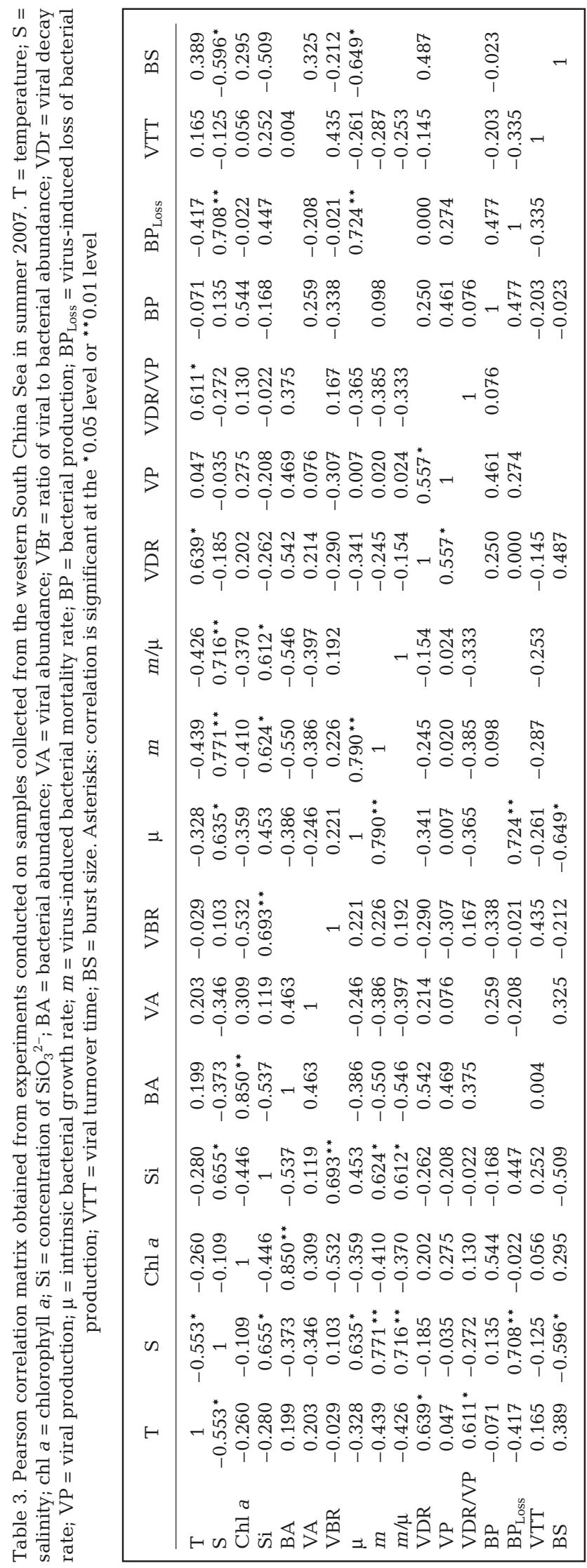

and $\mathrm{OO}$ waters (average $0.92 \pm 0.21,0.93 \pm 0.07$ and $1.02 \pm 0.10 \mathrm{~d}^{-1}$, respectively), while a significantly lower $m$ was found in the MR plume $\left(0.42 \pm 0.26 \mathrm{~d}^{-1}\right)$ (Table 4, Fig. 3i). The mortality rate decreased with bacterial abundance (Pearson's, $\mathrm{r}=-0.550, \mathrm{p}=0.052$, $\mathrm{n}=13$; Table 3 ) and was positively correlated with salinity (Pearson's, $\mathrm{r}=0.771, \mathrm{p}<0.01, \mathrm{n}=13$; Table 3 ), $\mathrm{SiO}_{3}{ }^{2-}$ (Pearson's, $\mathrm{r}=0.624, \mathrm{p}<0.05, \mathrm{n}=13$; Table 3 ) and bacterial growth rate (Pearson's, $\mathrm{r}=0.790, \mathrm{p}<$ 0.001, $\mathrm{n}=13$; Table 3, Fig. 5).

Among the 13 stations, bacterial production averaged $5.94 \pm 1.51 \mathrm{\mu g} \mathrm{Cl}^{-1} \mathrm{~d}^{-1}$. The highest bacterial production was found at Stn Y03 $\left(9.90 \mu \mathrm{g} \mathrm{Cl}^{-1} \mathrm{~d}^{-1}\right.$, in CE I), and the lowest was found at StnY86 $\left(4.17 \mu \mathrm{g} \mathrm{C} \mathrm{l}^{-1} \mathrm{~d}^{-1}\right.$, in the OO water) (Table 4; Fig. 3n). Bacterial production was higher in CE I and II (average $6.72 \pm 0.50$ and $6.85 \pm 2.64 \mu \mathrm{g} \mathrm{C} \mathrm{l}^{-1} \mathrm{~d}^{-1}$, respectively) than in the $\mathrm{OO}$ water and MR plume (average $5.01 \pm 0.77$ and $5.47 \pm$ $1.12 \mu \mathrm{g} \mathrm{Cl}^{-1} \mathrm{~d}^{-1}$, respectively) (Table 4; Fig. 3n). Bacterial production was positively correlated with $\mathrm{chl} a$ (Pearson's, $\mathrm{r}=0.544, \mathrm{p}<0.05, \mathrm{n}=13$; Table 3 ).

The average $\mathrm{BP}_{\text {Loss }}$ was $4.59 \pm 1.63 \mu \mathrm{g} \mathrm{Cl}^{-1} \mathrm{~d}^{-1}$ for all 13 stations investigated (Table 4). The highest $\mathrm{BP}_{\text {Loss }}$ was observed at Stn Y03 (7.63 $\left.\mu \mathrm{g} \mathrm{Cl}^{-1} \mathrm{~d}^{-1}\right)$ in CE II, and the lowest at Stn Y23 $\left(1.74 \mu \mathrm{g} \mathrm{C}^{-1} \mathrm{~d}^{-1}\right)$ in the MR plume (Table 4, Fig. 3o). $\mathrm{BP}_{\text {Loss }}$ was significantly lower (ANOVA, $\mathrm{p}<0.05, \mathrm{n}=13$ ) in the MR plume (average $2.69 \pm 0.12 \mu \mathrm{g} \mathrm{Cl}^{-1} \mathrm{~d}^{-1}$ ) than in CE I, CE II and OO water (average $5.63 \pm 1.17,5.73 \pm 1.67$ and $4.38 \pm 0.83 \mu \mathrm{g}$ $\mathrm{C}^{-1} \mathrm{~d}^{-1}$, respectively) (Table 4, Fig. 3o). $\mathrm{BP}_{\text {Loss }}$ was positively correlated with salinity (Pearson's, $r=0.708$, $\mathrm{p}<0.01, \mathrm{n}=13$; Table 3 ) and with bacterial growth rate (Pearson's, $\mathrm{r}=0.724, \mathrm{p}<0.01, \mathrm{n}=13$; Table 3 ).

Viruses caused approximately $77.82 \pm 20.12 \%$ loss of bacterial biomass produced per day (i.e. $\mathrm{m} / \mu$ ratio), with the highest loss at Stn TS-1 (96.08\%) in CE I and the lowest at Stn Y23 $(26.44 \%)$ in the MR plume (Table 4 , Fig. $3 \mathrm{j}$ ). The $\mathrm{m} / \mu$ ratio averaged $83.48 \pm$ $15.37,85.88 \pm 8.00,87.24 \pm 5.91$ and $51.57 \pm 26.80 \%$ in CE I, CE II, OO water and MR plume, respectively (Table 4, Fig. 3j), and was significantly lower in the MR plume than in the other 3 waters (ANOVA, p < $0.05, \mathrm{n}=13$ ). The $\mathrm{m} / \mu$ ratio was positively correlated with salinity (Pearson's, $\mathrm{r}=0.716, \mathrm{p}<0.01, \mathrm{n}=13$; Table 3) and with $\mathrm{SiO}_{3}{ }^{2-}$ (Pearson's, $\mathrm{r}=0.612$, $\mathrm{p}<$ $0.05, \mathrm{n}=13$; Table 3 ). The $\mathrm{m} / \mu$ ratio decreased with bacterial abundance (Pearson's, $\mathrm{r}=-0.546, \mathrm{p}=0.054$, $\mathrm{n}=13$; Table 3 ).

\section{Viral production and viral decay rate}

Viral production was about $1.03 \pm 0.39 \times 10^{6}$ viruses $\mathrm{ml}^{-1} \mathrm{~h}^{-1}$ in the investigated area (Table 4). The highest viral production appeared in CE I (Stn TS-1, $1.63 \pm 0.51$ 

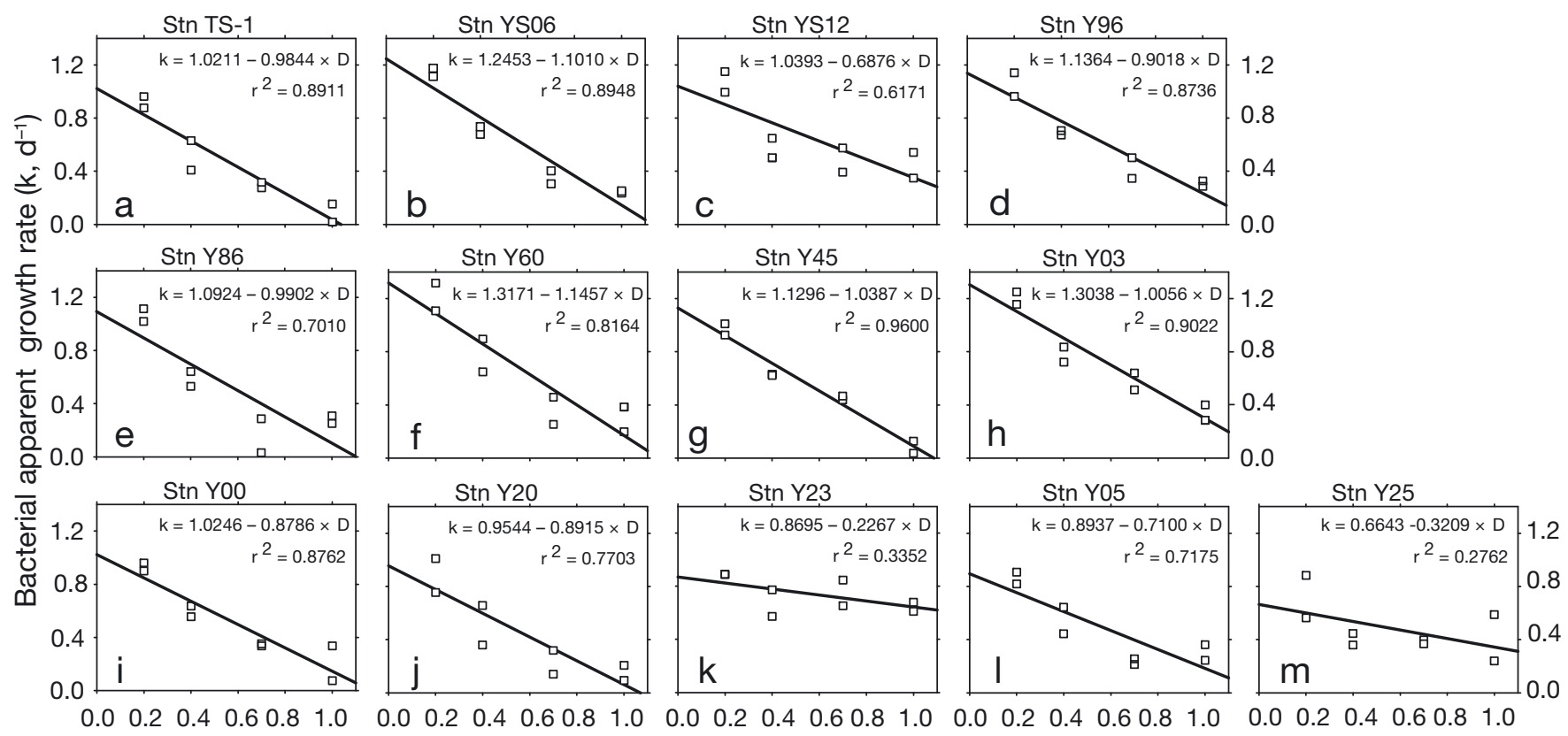

Fraction of whole water (D)

Fig. 4. Bacterial apparent growth rate against fraction of whole water for the parallel viral lysis dilution experiments conducted at 13 stations in the South China Sea in the summer of 2007. Equations describing the Model 1 linear regression for each station are given in every plot. Plots a-c were derived from stations located in Cold Eddy I, plots $\mathrm{h}-\mathrm{j}$ from stations located in Cold Eddy

II; and plots $\mathrm{k}-\mathrm{m}$ were from stations influenced by the Mekong River plume

$\times 10^{6}$ viruses $\left.\mathrm{ml}^{-1} \mathrm{~h}^{-1}\right)$ and CE II (Stn Y03; $1.60 \pm 0.22 \times$ $10^{6}$ viruses $\mathrm{ml}^{-1} \mathrm{~h}^{-1}$ ), while the lowest viral production was observed at Stn Y96 $\left(0.48 \pm 0.10 \times 10^{6}\right.$ viruses $\mathrm{ml}^{-1}$ $\mathrm{h}^{-1}$ ) in the OO water (Table 4, Fig. 31). Viral production in $\mathrm{CE}$ I was higher than in $\mathrm{OO}$ water (average $0.97 \pm$ $0.57 \times 10^{6}$ versus $0.85 \pm 0.46 \times 10^{6}$, respectively) as was that in CE II compared to MR plume (average $1.35 \pm$ $0.22 \times 10^{6}$ versus $1.00 \pm 0.07 \times 10^{6}$, respectively) (Table 4, Fig. 31). Viral production did not differ significantly among different waters (ANOVA, $\mathrm{p}>0.05, \mathrm{n}=$ 13; Table 4, Fig. 31). In the southern area, viral production was positively correlated with bacterial growth rate (Pearson's, r $=0.958, \mathrm{p}<0.01, \mathrm{n}=6$ ) and bacterial production (Pearson's, $r=0.861, \mathrm{p}<0.05, \mathrm{n}=6$ ). However, no significant relationship between viral production and bacterial growth rate or bacterial production was found in the northern area.

Viral decay rates were between 0.007 and $0.051 \mathrm{~h}^{-1}$ among the stations investigated (Table 4). At Stn Y86 in the $\mathrm{OO}$ water, the lowest viral decay rate $\left(0.007 \mathrm{~h}^{-1}\right)$ was observed, accompanied by the lowest viral abundance. Viral decay rates in the southern area (average $0.043 \pm 0.011 \mathrm{~h}^{-1}$ in CE II, and $0.037 \pm 0.007 \mathrm{~h}^{-1}$ in the MR plume) were higher than those in the northern area $\left(0.027 \pm 0.009 \mathrm{~h}^{-1}\right.$ in CE I, and $0.022 \pm 0.014 \mathrm{~h}^{-1}$ in the OO water) (Table 4, Fig. 3k). No significant difference (ANOVA, $p>0.05, n=13$ ) of viral decay rates was found between the different waters. Viral decay rates increased significantly with temperature (Pearson's, $\mathrm{r}=$ $0.639, \mathrm{p}<0.05, \mathrm{n}=13$ ) (Table 3 ). In addition, there was a correlation between viral production and viral decay rate (Pearson's, $\mathrm{r}=0.557, \mathrm{p}<0.05, \mathrm{n}=13$ ) (Table 3 ).

The ratio of viral decay rate to viral production (VDR/VP) was about $32.23 \pm 14.76 \%$, with the lowest at Stn TS-1 $(9.47 \%)$ in the OO water and the highest at

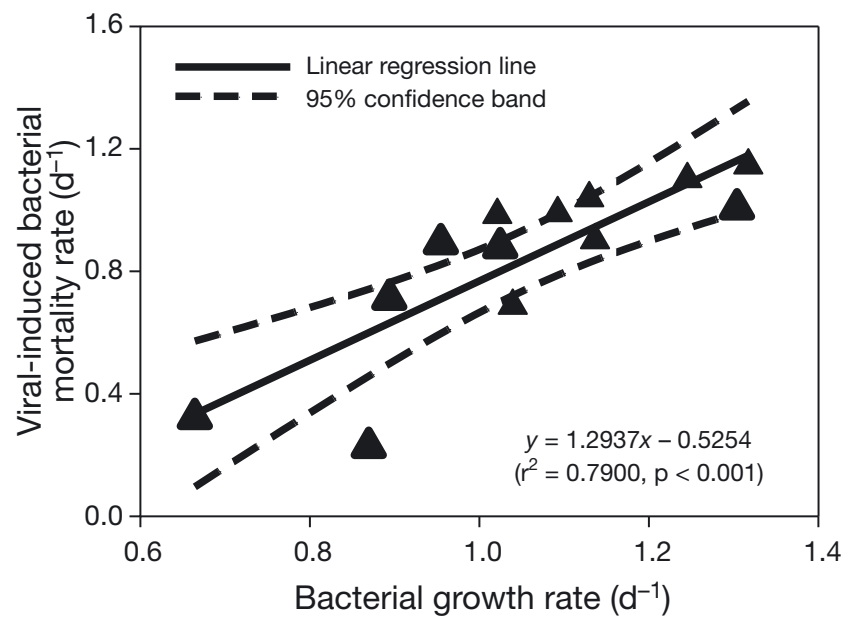

Fig. 5. Relationship between bacterial growth rate and virusinduced bacterial mortality rate in the South China Sea in the summer of 2007. Linear regression line and $95 \%$ confidence bands are shown. Equations describing the Model 1 linear regression $\left(y=y_{0}+a \times x\right)$ and $p$-value are shown 


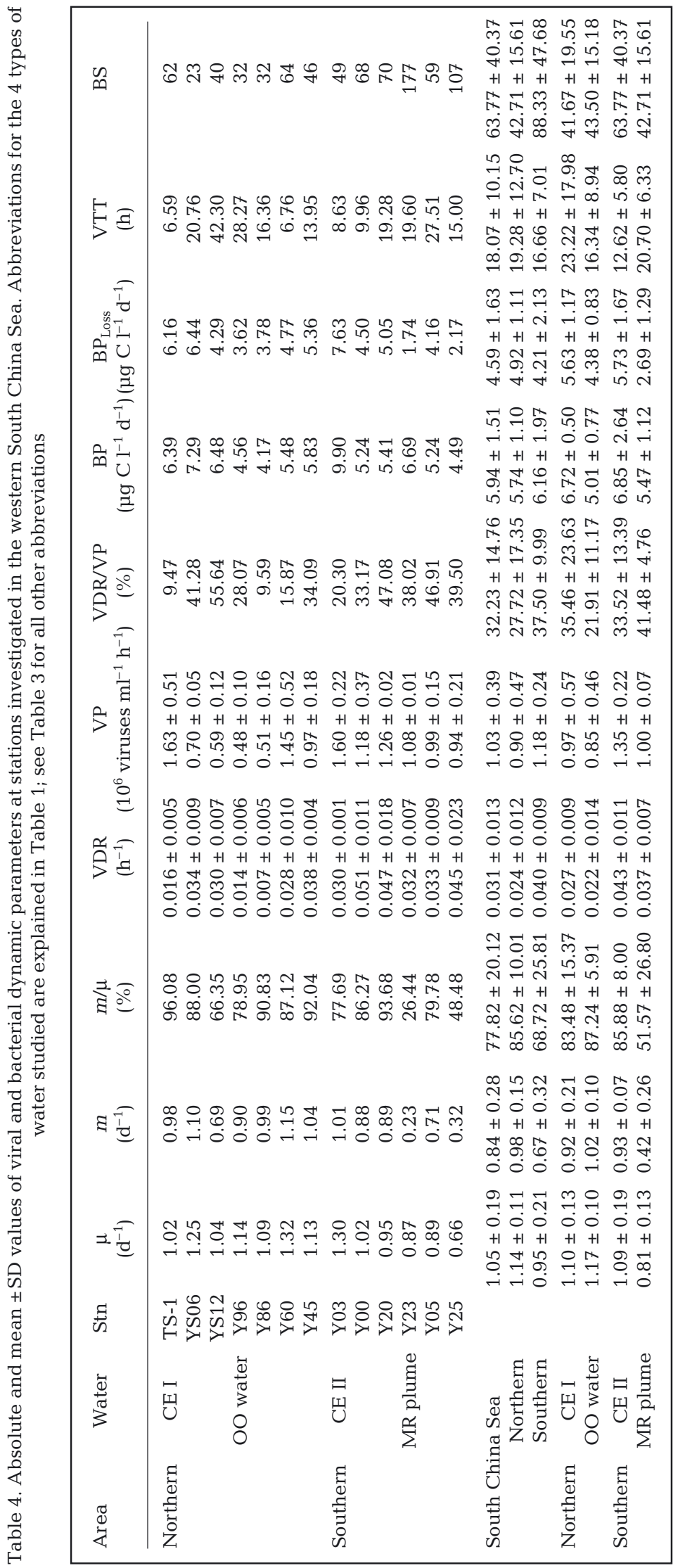

Stn YS12 (55.64\%) in CE I (Table 4, Fig. 3m). VDR/VP ranged from 9.47 to $55.64 \%$ in CE I, from 20.30 to $47.08 \%$ in CE II, from 9.59 to $34.09 \%$ in the OO water, and from 38.02 to $46.91 \%$ in the MR plume (Table 4, Fig. 3m). VDR/VP was higher in the MR plume (average $41.48 \pm 4.76 \%$ ), while it was lower in the OO water (average $21.91 \pm 11.17 \%$ ). The average VDR/VP was not significantly different among CE I and II, the MR plume and the OO water (ANOVA, $\mathrm{p}>0.05, \mathrm{n}=13$ ). VDR/VP significantly increased with temperature (Pearson's, $\mathrm{r}=0.611, \mathrm{p}<0.05, \mathrm{n}=13$ ) (Table 3).

\section{Viral turnover and burst size}

Viral turnover time among the stations studied was between $6.59 \mathrm{~h}$ (Stn TS-1 in CE I) and $42.30 \mathrm{~h}$ (Stn YS12 in CE II) and averaged 18.07 \pm 10.15 h (Table 4, Fig. 3p). Viral turnover times among different waters were not significantly different (ANOVA, $\mathrm{p}>0.05, \mathrm{n}=13$ ), about $23.22 \pm 17.98 \mathrm{~h}$ in CE I, $12.62 \pm 5.80 \mathrm{~h}$ in CE II, $16.34 \pm 8.94 \mathrm{~h}$ in the OO water and 20.70 $\pm 6.33 \mathrm{~h}$ in the MR plume (Table 4, Fig. $3 \mathrm{p}$ ).

Burst size ranged from 23 to 177 viruses cell $^{-1}$ among all stations (average $64 \pm 40$; Table 4, Fig. 3q). The highest burst size occurred at Stns Y23 and Y25 (177 and 107 viruses cell ${ }^{-1}$, respectively) in the MR plume (Table 4, Fig. 3q). The burst size in CE I (29.33 \pm 23.18 viruses cell ${ }^{-1}$ ) was smaller than in the surrounding $\mathrm{OO}$ water $(34.00 \pm 13.69$ viruses $\mathrm{cell}^{-1}$ ), and the pattern was the same for CE II and the surrounding MR plume $(40.67 \pm 5.69$ and $69.00 \pm 39.15$ viruses cell ${ }^{-1}$ for CE II and the MR plume, respectively) (Table 4, Fig. 3q). Burst size was negatively correlated with salinity (Pearson's, $\mathrm{r}=-0.596, \mathrm{p}<0.05, \mathrm{n}$ = 13; Table 3 ) and bacterial growth rate (Pearson's, $\mathrm{r}=-0.604, \mathrm{p}<0.05, \mathrm{n}=13$ ) (Table 3 ).

\section{DISCUSSION}

\section{Methodological issues}

Viral lysis

A modified Landry-Hassett dilution approach was used to explore the impact of viral lysis on bacterial mortality; this approach has several limitations (Evans et al. 2003, Bau- 
doux et al. 2006, 2007, Kimmance et al. 2007), which are discussed below.

First, the filtered seawater used to dilute samples might have contained nanoflagellates smaller than $2 \mu \mathrm{m}$, which consume both bacteria and viruses (Jacquet et al. 2005). It has been reported that grazing by heterotrophic flagellate assemblages removes only a small portion of viral abundance or production (González \& Suttle 1993, Bettarel et al. 2005), and our preliminary experiments also showed that this proportion was negligible for both viruses and bacteria (data not shown).

Second, ultrafiltration eliminates particulate organic matter and high-molecular-weight dissolved organic matter larger than $100 \mathrm{kDa}$. The exclusion of grazers might also reduce the generation of inorganic matter and the supply of labile dissolved organic matter for bacteria (Nagata 2000). Thus, the bacterial growth rate might be limited in viral lysis dilution experiments. On the other hand, because the virus-free water contains low-molecular-weight dissolved organic matter with no bacteria, the effect of substrate limitation caused by ultrafiltration and exclusion of grazers might be partially offset.

Third, a host density threshold, below which infection cannot take place (Wiggins \& Alexander 1985, Weinbauer \& Peduzzi 1994, Wilcox \& Fuhrman 1994), might have occurred due to bacterial abundance as low as $20 \%$ of the natural abundance in the most diluted bottles. If a threshold of $10^{4}$ cells ml-1 (Wiggins \& Alexander 1985) was used, bacterial abundance in our experiments did not fall below this thresholdeven in the most diluted treatment $(20 \%)$, where the lowest bacterial abundance was higher than $10^{5}$ cells $\mathrm{ml}^{-1}$ (Table 2). High viral abundance $\left(10^{6}\right.$ to $10^{7}$ viruses $\mathrm{ml}^{-1}$, Table 2) further demonstrated that contact rate and infection rate between bacteria and bacteriophages were not compromised in the dilution series. Moreover, the linear responses obtained from the dilution experiments in all 13 stations suggest that bacterial abundance was not diluted below this threshold level (Fig. 4).

\section{Viral production}

The dilution and re-occurrence approach has been increasingly used and has proved to be useful for estimating viral production in different aquatic environments (Wilhelm et al. 2002, Winter et al. 2004, Mei \& Danovaro 2004, Bongiorni et al. 2005). The 'modified virus dilution approach' following Bongiorni et al. (2005) in this study is much easier to manipulate in the field, when compared to the 'virus reduction approach' (Wilhelm et al. 2002). However, diluting hosts in the initial water by the 'modified virus dilution approach' would stimulate host growth rates and lytic cycles in the lysogenic infections, which might overestimate viral production. Because viral decay by colloidal and heat-labile substances still occurs in the diluted water, apparent viral production calculated from the incubated bottles should be revised by the viral decay rate to acquire viral production in situ. Thus, if infected bacterial abundances in the diluted bottle are too low, the development of viral abundance over time would barely be observed or might even show a decreasing pattern (pattern iii shown in Fig. 2b).

Five different patterns in the viral production curve were observed (Fig. 2b,c). Patterns $i$ and ii (Fig. 2b) showed an increasing viral abundance during incubation and had only 1 peak, which has commonly appeared in experiments using the 'virus reduction approach' (Wilhelm et al. 2002). However, most curves in our experiments had 2 peaks (patterns iv and $v_{i}$ Fig. 2c); similar patterns occurred in viral production dilution experiments conducted in the North Sea (Winter et al. 2004). Because the incubations in our experiments lasted for about $12 \mathrm{~h}$, some being mainly during the day and others at night, one possibility might be that there was a diel signal of viral infection and/or lysis in the SCS as in the North Sea, where viral lysis of bacteria occurred around noon to afternoon, and infection occurred mainly during the night (Winter et al. 2004). Another explanation might be the delay in viral production that occurs when using the dilution and reoccurrence approach (Weinbauer \& Suttle 1999).

\section{Dynamics of bacterial and viral abundances}

Bacterial abundance was positively related to chl $a$ (Table 3), which indicates that it is largely controlled by the labile dissolved organic matter produced by primary producers in the oligotrophic SCS. However, there was no significant relationship between viral abundance and chl a or between viral and bacterial abundance (Table 3). This may imply that, on a relatively short temporal scale and limited spatial scale, viral abundance in the oligotrophic SCS is determined neither by trophic status nor by host abundance. The lack of relationships described above is not unexpected because viral abundance is a dynamic combination of viral production and removal, both of which are influenced by many factors such as trophic status, mixing, UV radiation and turbidity (Suttle \& Chen 1992, Bongiorni et al. 2005) or by direct consumption by heterotrophic nanoflagellates (González \& Suttle 1993). 


\section{Bacterial growth rate and virus-induced bacterial mortality rate}

The bacterial growth rate in the SCS was comparable to rates determined by dilution approaches in oceanic waters, such as 1.0 to $1.1 \mathrm{~d}^{-1}$ in the North Sea (Yokokawa et al. 2004, calculated from Eilers et al. 2000) and $1.55 \mathrm{~d}^{-1}$ off Kuroshio, Japan (Yokokawa \& Nagata 2005). It has been reported that dilution approaches do not properly measure the in situ bacterial growth rate because of the dramatic change of taxonomic composition in diluted incubations (Fuchs et al. 2000); however, Yokokawa et al. (2004) suggested that artificial enhancement of bacterial growth rate was minimal.

Bacterial growth rate was positively correlated with salinity and $\mathrm{SiO}_{3}{ }^{2-}$, as was $m$ (Table 3 ). Because high salinity and nutrients are characteristics of deep water upwelled in cold eddies, the above relationships indicate that increasing trophic conditions enhance both $\mu$ and $m$. Similar findings have been reported along a trophic gradient in the North Adriatic Sea (Bongiorni et al. 2005). However, we did not observe any relationship between bacterial production and hydrological conditions (temperature and salinity) or trophic conditions $\left(\mathrm{SiO}_{3}{ }^{2-}\right.$ and $\mathrm{chl}$ a).

We observed a very high bacterial mortality caused by viral lysis (average $77.82 \pm 20.12 \%$ of daily growth; i.e. $m / \mu_{i}$ Table 4 ) among the investigated stations; this indicates that viral lysis plays an important role in bacterial mortality in the SCS. However, in the MR plume, low values of $\mathrm{m} / \mu$ and $\mathrm{BP}_{\text {Loss }}$ were found, together with a low $m$. All 3 parameters $(m$, $\mathrm{m} / \mu$ and $\mathrm{BP}_{\text {Loss }}$ ) were significantly lower in the $\mathrm{MR}$ plume than in CE I, CE II and OO water. In addition, at Stn YS12, where there was a bloom of Trichodesmium spp., $m$ and $m / \mu\left(0.69 \mathrm{~d}^{-1}\right.$ and $\left.66.35 \%\right)$ were much lower than at other stations in the northern area (Table 4). Thus, it can be concluded that viral lysis was not so heavily responsible for bacterial mortality in the MR plume and in the water containing the Trichodesmium spp. bloom. We speculated that bacterial and viral communities had shifted but were not in a steady state under the influence of the Mekong River plume and the Trichodesmium spp. bloom, and that the succession and mismatching between immature bacterial and viral communities were responsible for the low $m, m / \mu$ and $\mathrm{BP}_{\text {Loss. }}$ In addition, adsorption of viruses on particles (such as particulate organic matter and transparent exopolymeric particles) carried by the Mekong River freshwater, or formed by Trichodesmium spp., might reduce the viral infectivity and hence the infection rates, and consequently reduce $m, m / \mu$ and $\mathrm{BP}_{\text {Loss }}$ (Suttle \& Chen 1992, Noble \& Fuhrman 1997, Wein- bauer et al. 2009). A strong relationship between $\mu$ and $m$ observed in this study (Fig. 5) is in agreement with the findings of Middelboe (2000), which show that the rates of bacterial lysis are positively correlated with the host growth rates in chemostat cultures within a marine virus-host system. Furthermore, a higher contact rate between bacteria and viruses, resulting from higher bacterial growth, may be responsible for a higher $m$.

\section{Viral production and viral decay rate}

Using the dilution approaches, viral production was reported to range from $4 \times 10^{6}$ to $10^{7}$ viruses $\mathrm{ml}^{-1} \mathrm{~h}^{-1}$ in eutrophic waters (Wilhelm et al 2002, Bongiorni et al. 2005 ), and 0.20 to $1.1 \times 10^{6}$ viruses $\mathrm{ml}^{-1} \mathrm{~h}^{-1}$ in mesotrophic and oligotrophic waters (Winter et al. 2004, Bongiorni et al. 2005). In general, viral production in the SCS was comparable to that in oligotrophic and mesotrophic waters. The highest viral production was found at stations located in the cold eddies (Stns TS-1 and Y03, Table 4) and was comparable to viral production in mesotrophic waters (Wilhelm et al. 2002), which we believe to be related to high primary production in the cold eddies as indicated by high chl a. A previous study along a trophic gradient in the North Adriatic Sea reported similar findings and showed that higher rates of bacterial production and host cell metabolic activities can sustain higher viral production (Bongiorni et al. 2005). However, viral production had no apparent relationship with surface chl $a$, bacterial growth rate or bacterial production in this study (Table 3), suggesting that viral production may not be solely determined by trophic status in this part of the SCS. Nevertheless, we found that viral production in mesotrophic waters (the MR plume, CE I and II) was higher than in oligotrophic waters (the $\mathrm{OO}$ water). We speculate that the lack of significant relationships between viral production and water column trophic conditions was caused by complex hydrodynamics (cold eddies and the Mekong River plume) during our investigation.

To date, different approaches have been used to assess viral decay rates, and the data from different studies are thus difficult to compare (Parada et al. 2007). Here, we compare results from the SCS with previous studies in which dark-incubation of filtered or unfiltered seawater was used, as in this study. Viral decay rates in the SCS (range 0.007 to $0.051 \mathrm{~h}^{-1}$; Table 4) are a little higher than those found in coastal and oceanic environments, such as in the coastal seawaters of Texas (range 0 to $0.023 \mathrm{~h}^{-1}$; Suttle \& Chen 1992), in Santa Monica Bay (range 0.013 to $0.018 \mathrm{~h}^{-1}$; Noble \& Fuhrman 1997), in the North Sea (range 0.003 
to $0.017 \mathrm{~h}^{-1}$; Winter et al. 2004) and in the Mediterranean Sea $\left(0.020 \mathrm{~h}^{-1}\right.$; Guixa-Boixereu et al. 1999). In addition, viral decay rates in the surface SCS were about 1 magnitude higher than those found in the mesopelagic and bathypelagic waters of the North Atlantic (range 0.001 to $0.004 \mathrm{~h}^{-1}$; Parada et al. 2007). Differences in viral decay rates within different waters might be related to hydrological and biological differences. It has been reported that eutrophic systems, compared with oligotrophic systems, might promote higher viral decay rates (Bongiorni et al. 2005), and we did find that viral decay rates were significantly higher in the southern area, which received the Mekong River plume, than in the northern area (ANOVA, p $<0.05$, $\mathrm{n}=13$ ) (Table 4, Figs. 1 \& 3k). Furthermore, we found that viral decay rates increased with viral production, which might also imply that the trophic status determined viral decay rates. A previous study indicated that viral decay rates increased with temperature (Cottrell \& Suttle 1995), although the temperature gradient caused by the cold eddies and freshwater plume seemed to be very small $\left(\Delta T=1.9^{\circ} \mathrm{C}\right.$; Table 1 , Fig. 3a). In this study, viral decay rates significantly increased with seawater temperature, as reported in another study (Parada et al. 2007).

Colloid and heat-labile substances are important causes of viral removal, and the proportion of viral removal by these factors is different in eutrophic and oligotrophic waters; however, few data are available (Winter et al. 2004, Bongiorni et al. 2005). Combined with other data, such as viral removal by grazing, the proportion of viruses removed by colloid and heatlabile substances can help us to better estimate which pathway plays a more important role for viral removal. From the VDR/VP, we found that the proportion of viruses removed by colloidal and heatlabile substances differed from station to station (Table 4). The highest removal $(55.64 \%)$ was found at Stn YS12, where there was a bloom of the nitrogen-fixing cyanobacterium Trichodesmium during the sampling period. Trichodesmium is a filamentous, colonial cyanobacterium prevalent in tropical and subtropical waters, and it is also one of the dominant red-tide phytoplankton species. Previous studies have shown that the Trichodesmium bloom releases extracellular substances (photosynthetic precursors) during photosynthesis (Pant \& Devassy 1976), and an average of $50 \%$ of the $\mathrm{N}_{2}$ fixed by Trichodesmium is apparently released as dissolved organic nitrogen (Glibert \& Bronk 1994). Some of the extracellular matter and dissolved organic nitrogen released by Trichodesmium might be active enzymes or may further form colloids (i.e. colloidal and heat-labile substances), which might elevate the viral decay rate at this bloom-forming station (YS12) compared to other stations. At stations located in CE I and II, where the temperature was slightly lower, viral removal by colloidal and heat-labile substances was very low. Furthermore, a strong relationship between the temperature and VDR/VP (Table 3) indicates that colloidal and heat-labile substances play a more important role in viral removal when the seawater temperature is elevated. Because viral decay rates and the proportion of viral removal by colloidal and heat-labile substances were both sensitive to temperature, temperature fluctuation due to the cold eddies might play an important role in viral dynamics in the oligotrophic SCS.

\section{Viral turnover and burst size}

Viral turnover times calculated in this study are shorter (from hours to days, average 18.07 $\pm 10.15 \mathrm{~h}$ ) than those reported in other studies carried out in oceanic waters (on average $6.1 \mathrm{~d}$ ); however, they are comparable to those in coastal/shelf waters (on average 1.6 d) (Weinbauer 2004). The main reason for the discrepancy could be that different methods were used. Previous studies usually assessed viral turnover from viral decay rate on the assumption that viral decay rate is equal to viral production (Weinbauer 2004). However, this is not necessarily the case, because viral decay rates in some studies, such as that of Suttle \& Chen (1992), accounted for only those viruses removed by the colloidal and heat-labile substances in the water, but did not account for the total removal of viral production of the system, due to the method used (Bongiorni et al. 2005). Our results showed that viral turnover in the SCS in summer was high, especially in CE II. Other studies conducted during this cruise also showed moderately higher biological turnover rates in the cold eddies (Chen et al. 2009).

The average viral burst size (64) in the SCS was about 3 times that of the average burst size (23) calculated by Parada et al. (2006) for marine environments. A higher viral burst size was found at Stns Y23 and Y25 in the MR plume. It is known that the cell size of the host may directly determine viral burst size (Parada et al. 2006). Our results could be due to the higher dissolved organic and inorganic nutrient input from river water which might induce a larger bacterial size and sequentially a higher burst size of the infected bacteria at the above stations. Negative correlation of salinity with burst size further supports the above explanation (Table 3). It is also suggested that viral burst size increases with the trophic status of the environment and bacterial production (Parada et al. 2006). However, such trends were not apparent among our investigations (Table 3). 


\section{Comparison of biological parameters among different waters}

In this study, the Mekong River plume and cold eddies might influence the phytoplankton, bacteria and viruses in 2 ways. First, the freshwater plume or upwelled water may change the physical and trophic conditions, such as temperature, salinity, nutrients and dissolved organic matter. Second, the plume or subsurface bacterial and viral communities mix with the surface ocean communities and form non-steady-state bacterial and viral communities.

The fact that no significant differences were found in chl $a$, bacterial and viral dynamic parameters between CE I and II (Tables 1, 2 \& 4) implies that the cold eddies formed in summer in the SCS may stimulate similar biological responses. From significantly lower chl a and bacterial abundance in the OO water - compared to the CE I, CE II and MR plume (Tables 1 \& 2) - and elevated viral abundance, viral decay rates, viral production and VDR/VP with enhanced nutrients, it is evident that substrate input (nutrients and organic matter) from the deep layer (cold eddies) or the river plume enhanced the standing stock of the microbial community (primary producer, bacteria and viruses).

Significantly lower bacterial growth rates, $m, m / \mu$, and $\mathrm{BP}_{\text {Loss }}$ in the MR plume, compared to CE I, CE II and the $\mathrm{OO}$ water, and no significant differences among the latter 3 waters (Table 4 ), indicate that bacterial and viral activities have distinct responses to the upwelling of cold subsurface water (stable activity) and the freshwater plume (decreasing activity). It is known that nutrients and dissolved organic matter upwelling from the deep sea are mineralized from the particulate organic matter sinking from the upper layer, and might be as homogeneous as those in the upper layer. In contrast, nutrients and dissolved organic matter from freshwater sources are quite heterogeneous when compared with those present in oceanic water. Because freshwater and marine environments have very different bacterial community structures (Cottrell \& Kirchman 2004), we speculate that the influence of freshwater on changes in the in situ bacterial community structure would be dramatic and it would take time to form a mature (steady state) community for the mixed water, while the influence of deep water should be a mild and equilibrated process. The adjustment of bacterial and viral communities in the MR plume could cause low bacterial and viral activities. Therefore, when compared with the OO water, the homogeneousness of nutrients and dissolved organic matter might explain the constant bacterial and viral activities in CE I and II, whereas the heterogeneousness might explain the decrease in bacterial and viral activities in the MR plume. Another explanation for the constant bacterial and viral activities in CE I and II is simply that the subsurface cold water did not reach the surface, and thus had limited impact on bacterial community structure or physiology. In short, the stability of the environments in question might determine bacterial and viral activities.

\section{CONCLUSIONS}

This study provides data on comprehensive viral dynamic parameters simultaneously, including viral production, viral decay rate, virus-induced bacterial mortality rate, viral turnover time and burst size in the western

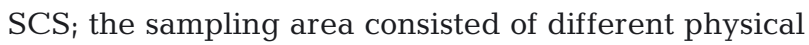
settings - from mesoscale cold eddies to the influences of a freshwater plume. Modest viral production and viral decay rates were observed, and viral production was higher in mesotrophic waters (freshwater plume and cold eddies) compared with oligotrophic SCS waters. Within the temperature gradient generated by the cold eddies or the freshwater plume, viral decay rate and the proportion of viruses removed by colloidal and heat-labile substances showed a significantly negative response to low temperature. Viral lysis was one of the most important causes of bacterial mortality in the western SCS in summer, and the virus-induced bacterial mortality rate was determined by bacterial activity. We found that the biological standing stock was largely determined by the trophic status, while bacterial and viral activities might be influenced by the stability of waters. Because the mechanisms controlling viral dynamics in different marine environments are still not clear, more studies are needed to better understand the role of viruses in biogeochemical processes.

Acknowledgements. The authors thank Xiamen University for providing the opportunity to attend the cruise. Thanks to Prof. Minhan Dai and Jianyu Hu for providing the hydrographic and nutrient data and Tingwei Luo for technical support of flow cytometry. Special thanks are given to the 3 anonymous peer reviewers because their critical comments have greatly improved the quality of this manuscript. This work was supported by Hong Kong RGC (RGF grants HKUST661407 and 661809) and the TUYF Charitable Trust (TUYF10SC08) to HL. We also acknowledge the support from the Ministry of Science and Technology of China through the National Basic Research Program (2009CB421203).

\section{LITERATURE CITED}

Baudoux AC, Noordeloos AA, Veldhuis MJ, Brussaard CPD (2006) Virally induced mortality of Phaeocystis globosa during two spring blooms in temperate coastal waters. Aquat Microb Ecol 44:207-217

> Baudoux AC, Veldhuis MJ, Witte HJ, Brussaard CP (2007) Viruses as mortality agents of picophytoplankton in the 
deep chlorophyll maximum layer during IRONAGES III. Limnol Oceanogr 52:2519-2529

Bettarel Y, Sime-Ngando T, Bouvy M, Arfi R, Amblard C (2005) Low consumption of virus-sized particles by heterotrophic nanoflagellates in two lakes of the French Massif Central. Aquat Microb Ecol 39:205-209

Bidigare RR, Benitez-Nelson C, Leonard CL, Quay PD, Parsons ML, Foley DG, Seki MP (2003) Influence of a cyclonic eddy on microheterotroph biomass and carbon export in the lee of Hawaii. Geophys Res Lett 30,1318 doi:10.1029/ 2002GL016393

> Binder B (1999) Reconsidering the relationship between virally induced bacterial mortality and frequency of infected cells. Aquat Microb Ecol 18:207-215

Bongiorni L, Magagnini M, Armeni M, Noble R, Danovaro R (2005) Viral production, decay rates, and life strategies along a trophic gradient in the North Adriatic Sea. Appl Environ Microbiol 71:6644-6650

Brussaard CPD (2004) Optimization of procedures for counting viruses by flow cytometry. Appl Environ Microbiol 70:1506-1513

Chen B, Liu H, Landry MR, Dai M, Huang B, Sun J (2009) Close coupling between phytoplankton growth and microzooplankton grazing in the western South China Sea. Limnol Oceanogr 54:1084-1097

Cochlan WP, Wikner J, Steward GF, Smith DC, Azam F (1993) Spatial distribution of viruses, bacteria, and chlorophyll a in neritic, oceanic and estuarine environments. Mar Ecol Prog Ser 92:77-87

> Corinaldesi C, Crevatin E, Del Negro P, Marini M, Russo A, Fonda-Umani S, Danovaro R (2003) Large-scale spatial distribution of virioplankton in the Adriatic Sea: testing the trophic state control hypothesis. Appl Environ Microbiol 69:2664-2673

Cottrell MT, Kirchman DL (2004) Single-cell analysis of bacterial growth, cell size, and community structure in the Delaware estuary. Aquat Microb Ecol 34:139-149

Cottrell MT, Suttle CA (1995) Dynamics of a lytic virus infecting the marine picoflagellate Micromonas pusilla. Limnol Oceanogr 40:730-739

> De Paepe MD, Taddei F (2006) Viruses' life history: towards a mechanistic basis of a trade-off between survival and reproduction among phages. PLoS Biol 4:e193

Eilers H, Pernthaler J, Amann R (2000) Succesion of pelagic marine bacteria during enrichment: a close look at cultivation-induced shifts. Appl Environ Microbiol 66:4634-4640

$>$ Evans C, Archer SD, Jacquet S, Wilson WH (2003) Direct estimates of the contribution of viral lysis and microzooplankton grazing to the decline of a Micromonas spp. population. Aquat Microb Ecol 30:207-219

Falkowski PG, Ziemann D, Kolber Z, Bienfang PK (1991) Role of eddy pumping in enhancing primary production in the ocean. Nature 352:55-58

Fuchs BM, Zubkov MV, Sahm K, Burkill PH, Amann R (2000) Changes in community composition during cultures of marine bacterioplankton as assessed by flow cytometric and molecular biological techniques. Environ Microbiol 2:191-201

Fuhrman JA (1999) Marine viruses and their biogeochemical and ecological effects. Nature 399:541-548

Fuhrman JA, Nobel RT (1995) Viruses and protists cause similar bacterial mortality in coastal seawater. Limnol Oceanogr 40:1236-1242

Glibert PM, Bronk DA (1994) Release of dissolved organic nitrogen by marine diazotrophic cyanobacteria, Trichodesmium spp. Appl Environ Microbiol 60:3996-4000

> González JM, Suttle CA (1993) Grazing by marine nanoflagellates on viruses and virus-sized particles: ingestion and digestion. Mar Ecol Prog Ser 94:1-10

Guixa-Boixereu N, Vaqué D, Gasol JM, Pedrós-Alió C (1999) Distribution of viruses and their potential effect on bacterioplankton in a oligotrophic marine system. Aquat Microb Ecol 19:205-213

> Hara S, Koike I, Terauchi K, Kamiya H, Tanoue E (1996) Abundance of viruses in deep oceanic waters. Mar Ecol Prog Ser 145:269-277

> Hewson I, O'Neil JM, Dennison WC (2001) Virus-like particle distribution and abundance in sediments and overlying waters along eutrophication gradients in two subtropical estuaries. Limnol Oceanogr 46:1734-1746

Jacquet S, Domaizon I, Personnic S, Ram ASP, Hedal M, Duhamel S, Sime-Ngando T (2005) Estimates of protozoan- and viral-mediated mortality of bacterioplankton in Lake Bourget (France). Freshw Biol 50:627-645

Kimmance SA, Wilson WH, Archer SD (2007) Modified dilution technique to estimate viral versus grazing mortality of phytoplankton: limitations associated with method sensitivity in natural waters. Aquat Microb Ecol 49: $207-222$

> Landry MR, Hassett RP (1982) Estimating the grazing impact of marine microzooplankton. Mar Biol 67:283-288

Liu H, Chang J, Tseng CM, Wen LS, Liu KK (2007) Seasonal variability of picoplankton in the Northern South China Sea at the SEATS station. Deep-Sea Res II 54:1602-1616

McGillicuddy DJ Jr, Robinson AR, Siegel DA, Jannasch HW and others (1998) Influence of mesoscale eddies on new production in the Sargasso Sea. Nature 394:263-266

Mei ML, Danovaro R (2004) Virus production and life strategies in aquatic sediments. Limnol Oceanogr 49:459-470

- Middelboe M (2000) Bacterial growth rate and marine virus-host dynamics. Microb Ecol 40:114-124

Nagata T (2000) Production mechanisms of dissolved organic matter. In: Kirchman DL (ed) Microbial ecology of the oceans. John Wiley, New York, NY, p 121-152

Noble RT, Fuhrman JA (1997) Virus decay and its causes in coastal waters. Appl Environ Microbiol 63:77-83

> Noble RT, Fuhrman JA (1999) Breakdown and microbial uptake of marine viruses and other lysis products. Aquat Microb Ecol 20:1-11

Noble RT, Fuhrman JA (2000) Rapid virus production and removal as measured with fluorescently labeled viruses as tracers. Appl Environ Microbiol 66:3790-3797

> Olson RJ, Chisholm SW, Zettler ER, Altabet MA, Dusenberry JA (1990) Spatial and temporal distributions of prochlorophyte picoplankton in the North Atlantic Ocean. DeepSea Res 37:1033-1051

Pant A, Devassy V (1976) Release of extracellular matter during photosynthesis by a Trichodesmium bloom. Curr Sci 45:487-489

Parada V, Herndl GJ, Weinbauer MG (2006) Viral burst size of heterotrophic prokaryotes in aquatic systems. J Mar Biol Assoc UK 86:613-621

> Parada V, Sintes E, Van Aken HM, Weinbauer MG, Herndl GJ (2007) Viral abundance, decay, and diversity in the meso- and bathypelagic waters of the North Atlantic. Appl Environ Microbiol 73:4429-4438

Parsons TR, Maita Y, Lalli CM (1984) Manual of chemical and biological methods for seawater analysis. Pergamon Press, Oxford

> Payment P, Morin E, Trudel M (1988) Coliphages and enteric viruses in the particulate phase of river water. Can J Microbiol 34:907-910

> Suttle CA, Chen F (1992) Mechanisms and rates of decay of marine viruses in seawater. Appl Environ Microbiol 58: 3721-3729 
Vaulot D, Couties C, Partensky F (1989) A simple method to preserve oceanic phytoplankton for flow cytometric analysis. Cytometry 10:629-635

> Wang D, Xu H, Lin J, Hu J (2008) Anticyclonic eddies in the northeastern South China Sea during winter 2003/2004. J Oceanogr 64:925-935

Weinbauer MG (2004) Ecology of prokaryotic viruses. FEMS Microbiol Rev 28:127-181

> Weinbauer MG, Peduzzi P (1994) Frequency, size and distribution of bacteriophages in different marine bacterial morphotypes. Mar Ecol Prog Ser 108:11-20

Weinbauer MG, Suttle CA (1999) Lysogeny and prophage induction in coastal and offshore bacterial communities. Aquat Microb Ecol 18:217-225

Weinbauer MG, Fuks D, Peduzzi P (1993) Distribution of viruses and dissolved DNA along a coastal trophic gradient in the Northern Adriatic Sea. Appl Environ Microbiol 59:4074-4082

Weinbauer MG, Brettar I, Höfle M (2003) Lysogeny and virusinduced mortality of bacterioplankton in surface, deep, and anoxic waters. Limnol Oceanogr 48:1457-1465

Weinbauer MG, Bettarel Y, Cattaneo R, Luef B and others (2009) Viral ecology of organic and inorganic particles in aquatic systems: avenues for further research. Aquat Microb Ecol 57:321-341

Wiggins BA, Alexander M (1985) Minimum bacterial density for bacteriophage replication: implications for significance

Editorial responsibility: Curtis Suttle,

Vancouver, Canada of bacteriophages in natural ecosystems. Appl Environ Microbiol 49:19-23

Wilcox RM, Fuhrman JA (1994) Bacterial viruses in coastal seawater: lytic rather than lysogenic production. Mar Ecol Prog Ser 114:35-45

Wilhelm SW, Suttle CA (1999) Viruses and nutrient cycles in the sea - Viruses play critical roles in the structure and function of aquatic food webs. BioScience 49:781-788

Wilhelm SW, Weinbauer MG, Suttle CA, Jeffrey WH (1998) The role of sunlight in the removal and repair of viruses in the sea. Limnol Oceanogr 43:586-592

Wilhelm SW, Brigden SM, Suttle CA (2002) A dilution technique for the direct measurement of viral production: a comparison in stratified and tidally mixed coastal waters. Microb Ecol 43:168-173

> Winter C, Herndl GJ, Weinbauer MG (2004) Diel cycles in viral infection of bacterioplankton in the North Sea. Aquat Microb Ecol 35:207-216

Wommack KE, Colwell RR (2000) Virioplankton: viruses in aquatic ecosystems. Microbiol Mol Biol Rev 64:69-114

- Yokokawa T, Nagata T (2005) Growth and grazing mortality rates of phylogenetic groups of bacterioplankton in coastal marine environments. Appl Environ Microbiol 71: 6799-6807

> Yokokawa T, Nagata T, Cottrell MT, Kirchman DL (2004) Growth rate of the major phylogenetic bacterial groups in the Delaware estuary. Limnol Oceanogr 49:1620-1629

Submitted: December 21, 2009; Accepted: January 4, 2011 Proofs received from author(s): March 18, 2011 